\section{Cold Hardiness of Phellodendron sachalinense Friedr. Schmidt Seedlings Increases with Age}

\author{
Steve McNamara ${ }^{1}$ and Harold Pellett ${ }^{2}$ \\ Department of Horticultural Science, University of Minnesota, Minnesota \\ Landscape Arboretum, Chanhassen, MN 55317-0039 \\ Additional index words. freezing injury, tree seedling, cold acclimation, juvenility, corktree
}

\begin{abstract}
Seedlings of several landscape tree species frequently experience cold injury at temperatures that are noninjurious to older specimens of the same species. However, there are few published reports quantifying age-related differences in hardiness. In this study, the stem cold hardiness of a mature, 35-year-old female Sakhalin corktree was compared with that of half-sib seedling progeny of different ages. Ten-, 22-, and 34-month-old seedlings were hardy to $-4{ }^{\circ} \mathrm{C}$ on 9 Oct., while the 35 -year-old parent withstood $-12{ }^{\circ} \mathrm{C}$. Ten-month-old seedlings exhibited no further increase in hardiness on 26 Oct., whereas the 34-month-old seedlings and the mature parent were hardy to $-16{ }^{\circ} \mathrm{C}$. The 22 -monthold seedlings were intermediate in hardiness on this date. The 10- and 22-month-old seedlings had died back to the snowline by late January, but the 34-month-old seedlings and the mature tree were uninjured. The corktree seedlings did not attain midwinter hardiness levels comparable to the adult tree until the winter following their fourth season of growth. The absence of flower buds on cold-tolerant 4- and 5-year-old seedlings suggests that physiological maturation is not a prerequisite for full expression of the cold acclimation capability of this species.
\end{abstract}

Field-grown seedlings of several valuable landscape tree species frequently experience cold injury at temperatures that are noninjurious to older specimens of the same species. In Minnesota, we have observed this phenomenon on red maple (Acer rubrum L.), eastern redbud (Cercis canadensis L.), and corktree (Phellodendron sp.). Young seedlings of these species seem unresponsive to photoperiod and temperature cues that trigger the cold acclimation process in older trees, and often continue to grow actively until the first incident of subfreezing temperatures. From a practical perspective, this phenomenon prevents field production of seedlings of these species in cold climates, including progeny from controlled hybridization and seedling rootstocks used for propagation of superior genotypes.

Although little is known about the relationship between age and cold hardiness for most woody plant taxa, the results of several studies indicate that the effect of age on cold acclimation capacity differs among species. Onemonth-old black locust (Robinia pseudoacacia L.) seedlings exposed to a regime of decreasing photoperiod and cool temperatures were killed at $0{ }^{\circ} \mathrm{C}$, whereas similarly treated 3month-old seedlings were not injured at -20 ${ }^{\circ} \mathrm{C}$ (Brown and Bixby, 1976). Similarly, veg-

Received for publication 5 Apr. 1999. Accepted for publication 1 Aug. 1999. Journal Series Paper number 981210030 of the Minnesota Agricultural Experiment Station. The cost of publishing this paper was defrayed in part by the payment of page charges. Under postal regulations, this paper therefore must be hereby marked advertisement solely to indicate this fact.

${ }^{1}$ Scientist.

${ }^{2}$ Professor. etative bud hardiness of seedlings of three grape (Vitis sp.) cultivars increased with age until the plants were 4 years old (Hubackova, 1994.). However, 36-day-old ponderosa (Pinus ponderosa Douglas ex Lawson) and lodgepole (Pinus contorta Douglas ex Loud) pine seedlings had higher mortality rates at $-8{ }^{\circ} \mathrm{C}$ than did 22-day-old seedlings (Cochran and Berntsen, 1973). Four- and 5-month-old seedlings of red-osier dogwood (Cornus sericea L.) acclimated to the same extent as rooted cuttings from mature plants in response to a warm $\left(20^{\circ} \mathrm{C}\right.$ day $/ 15^{\circ} \mathrm{C}$ night $)$, short-day (8-h) treatment (Hummel, 1981). The hardiness of younger dogwood seedlings was not characterized.

The objective of this study was to evaluate the cold hardiness of seedling and mature Sakhalin corktree plants during the fall acclimation period to determine whether cold hardiness varied with age. Corktree was selected for the study based upon previous observations of differences in severity of cold injury among seedlings of varying ages in our nurseries.
Beginning in 1987, seeds of Sakhalin corktree were collected in the fall of three successive years from a single, mature, female specimen growing at the Univ. of Minnesota Landscape Arboretum in Chanhassen (lat. $\left.44^{\circ} 50^{\prime} \mathrm{N}\right)$. Each year, seeds were moist-chilled (stratified) for $60 \mathrm{~d}$ and germinated over bottom-heat in a greenhouse in December. Approximately 1 -month-old seedlings were transplanted into No. 1 (3.2-L) containers containing a peat-based growing medium (Pro-Mix; Premier Brands, Red Hill, Pa.). A 16-h photoperiod was provided by $1000-\mathrm{W}$ high-pressure sodium lamps and plants were irrigated biweekly with a liquid fertilizer solution $(20 \mathrm{~N}-$ 7.7P-15.7K; Peters 20-18-19; Grace-Sierra Co., Milpitas, Calif.) containing $100 \mathrm{mg} \cdot \mathrm{L}^{-1} \mathrm{~N}$ at $\mathrm{pH}$ 6.0. The three half-sib populations produced from seed collected in 1987, 1988, and 1989 were $\approx 10,22$, and 34 months old, respectively, at the time of initial cold hardiness testing in Oct. 1990.

In late May, 25 uniform seedlings of each population were moved outdoors into a lathcovered greenhouse (50\% light transmission) for 2 weeks prior to being transplanted into the nursery at a spacing of $1 \mathrm{~m}$ in the row. Supplemental irrigation was provided via drip irrigation to all seedling populations as needed throughout the growing season and discontinued in mid-September.

Cold hardiness levels of the 1987 and 1988 seedling populations were not determined during the first two winters in the field. However, we observed that both 10-month-old and 10- and 22-month-old seedlings died back to the snow line in the winters of 1988-89 and 1989-90, respectively, whereas no injury was detected on the female parent. Injured seedlings resprouted from the base and were pruned up to a single leader in the spring.

Shoot cold hardiness of 10-, 22-, and 34month-old seedlings and the female parent tree were determined in the laboratory as described previously (McNamara and Pellett, 1996) on 9 and 26 Oct. 1990 and 25 Jan. 1991. Preliminary tests revealed that, with the exception of the two uppermost nodes, which were often quite succulent, there was no discernible positional effect on the hardiness of internodal sections collected from the top 60 $\mathrm{cm}$ of the seedling stems. Therefore, laboratory freezing tests were conducted on $4-\mathrm{cm}$ stem sections prepared after discarding the top
Table 1. Lowest survival temperatures $\left({ }^{\circ} \mathrm{C} \pm \mathrm{SD}\right)$ of Phellodendron sachalinense stem sections from seedlings of three different ages and the mature female parent.

\begin{tabular}{lcccc}
\hline Sampling & \multicolumn{4}{c}{ Age $^{\mathrm{z}}$} \\
\cline { 2 - 5 } date, 1990-91 & 10 months & 22 months & 34 months & $35 \mathrm{yr}$ \\
\hline 9 Oct. & $-5(1)$ & $-4(1)$ & $-4(0)$ & $-14(1)$ \\
26 Oct. & $-5(1)$ & $-8(2)$ & $-15(1)$ & $-16(2)$ \\
25 Jan. & $--^{\mathrm{y}}$ & $---^{\mathrm{y}}$ & $-37(1)$ & $-40(0)^{\mathrm{x}}$ \\
\hline
\end{tabular}

${ }^{\mathrm{z}}$ Age of plants on first sampling date.

${ }^{y}$ Seedlings killed to the ground prior to sampling.

${ }^{x}$ Samples were not killed at the lowest test temperature. 
two internodes. On each date, shoot material from 5-6 seedlings within each age group was combined and five stem sections of each group were exposed to each test temperature. The lowest survival temperature (LST) was determined from the number of stems killed at each test temperature. The standard deviation of each LST value was calculated to reflect the degree of variation in hardiness among individual replicates (Lindstrom and Del Hierro, 1992).

\section{Results and Discussion}

No differences in stem cold hardiness were detected among the 10-, 22-, and 34-monthold seedlings on the earliest sampling date, but all three groups were significantly less hardy than the 35-year-old female parent (Table 1). By 26 Oct., seedling cold hardiness was positively correlated with age $(r=0.91)$ with 34 month-old plants obtaining hardiness levels comparable with that of the female parent. By the late-January test, all of the 10- and 22month-old seedlings had been killed to the ground, whereas the 34-month-old seedlings and the mature parent tree were uninjured (daily minimum temperatures of $-31^{\circ} \mathrm{C}$ were recorded twice during the last week of Dec. 1990). The 34-month-old seedlings did not achieve the same maximum midwinter hardiness level as the mature parent tree. The greater capacity for cold acclimation exhibited by the 34-month-old seedlings relative to the younger populations did not appear to be associated with attainment of physiological maturity, as the plants did not bear flowers in Spring 1991. Additional testing of these populations performed in 1992-93 (data not shown) revealed that corktree seedlings were able to achieve midwinter hardiness levels comparable to that of the maternal parent after their fourth season of growth, when they were still physiologically immature.

In an additional comparison on 6 Oct. 1990 , we found that 18 -year-old eastern redbud trees were substantially more cold hardy than 5-year-old plants from the same seed source ( -22 vs. $-8{ }^{\circ} \mathrm{C}$, respectively). These results provide additional evidence that seedlings of certain woody plant species undergo an age-related transition of an unknown nature that promotes full expression of their genetic capacity for cold acclimation. Further study of these species might provide useful insights into the biochemical and biophysical processes underlying cold acclimation.

\section{Literature Cited}

Brown, G.N. and J.A. Bixby. 1976. Relationship between black locust seedling age and induction of cold hardiness. For. Sci. 22:208-210.

Cochran, P.H. and C.M. Berntsen. 1973. Tolerance of lodgepole and ponderosa pine seedlings to low night temperatures. For. Sci. 19:272-280.

Hubackova, M. 1994. The grapevine buds cold hardiness in juvenile plants. Ochr. Rostl. 30:305309.

Hummel, R. 1981. Temperature, prolonged short day, environmental preconditioning, and plant age effects on the acclimation response in Cornus sericea L. red-osier dogwood. PhD Diss., Univ. of Minnesota, St. Paul.

Lindstrom, O. and K. Del Hierro. 1992. Leaf and stem cold hardiness estimates of six selections of Chinese evergreen oak over two winter seasons. J. Environ. Hort. 10:11-13.

McNamara, S. and H. Pellett. 1996. Cold hardiness of flowering crabapple cultivars. J. Environ. Hort. 14:111-114. 